\title{
Berita Online Sebagai Instrumen Dakwah: Antara Profetik dan Provokatii
}

\author{
Analisis Framing Media Online Serambinews.com \\ dan Panjimas.com Terhadap Pemberitaan LGBT
}

\author{
Efa Rubawati \\ Mahasiswa Pascasarjana Prodi Media \& Komunikasi \\ Universitas Airlangga Surabaya \\ rubawatiefa@gmail.com
}

Abstract: The presenting of internet as the new media with high interactivity and connectivity, the fact has made almost the humans life undergoes the changing. It is not except for dimension of religion. The one of religion activity is preaching undergoing transformation from the conventional media to new media. Presently, a lot of online news in one side gives positive effect in deployment the fast and broad information, but in other side it becomes the place of developing the news false (hoax). Although, the news online is many still entering the preaching's messages in its news. One of them is serambinews.com dan panjimas.com. The study in this paper uses a study through descriptive method with framing media analysis. Sources of data were obtained from various sources and references related to the topic of discussion, both are from online internet and book literature. This study finds important things such as preaching of bil qalam can be done through news, although in the delivery of messages of preaching, these two online media have different framing. Understandably, serambinews.com conveys prophetic messages to the reader through the news, while panjimas.com chooses to present it provocatively. Both have their 
own advantages and disadvantages, which can be adapted to the conditions and assumptions of the community as mad'u.

Keywords: Media Online, Framing Media, Prophetic, Provocative.

\section{Pendahuluan}

Hadirnya internet sebagai media baru yang memiliki keunggulan dalam interaksi dan konektivitas yang tinggi dewasa ini telah memungkinkan komunikasi yang lebih konvergensif membedakannya dengan pola komunikasi konvensional. Komunikasi menjadi lebih mudah, tak terbatas ruang dan waktu, serta murah dan terbuka. Perkembangan media internet saat ini telah dibayangkan oleh Marshall McLuhan sejak awal 1960-an, seperti lahirnya pasar online, kampanye online, hingga kehidupan keagamaan yang menggunakan internet dalam berbagai fungsi dan sifatnya. Aguilar menunjukkan bahwa media digital merupakan sumber yang menghadirkan agama dalam berbagai dimensinya, walaupun tidak jarang terjadi penolakan penggunaan internet bagi tujuan agama karena dianggap internet mengandung ancaman normanorma sosial agama dan otoritas pemimpin agama. ${ }^{1}$

Dimensi agama dalam media berbasis internet merupakan tanda dari proses kebudayaan secara meluas, yang menyangkut ruang partisipasi dakwah yang terbuka. Sebelumnya publik (sebagai mad'u) ditempatkan sebagai objek dalam proses dakwah, kemudian menjadi subyek aktif yang terlibat dalam proses produksi pengetahuan agama. Makna agama tidak hanya diresepsi tetapi dimaknai berdasarkan latar belakang dan juga kepentingan publik sendiri. Pemahaman agama dan penyampainnya kepada publik melalui internet tergantung pemahaman dan pengetahuan individu yang secara aktif menjadi subyek sekaligus objek dakwah sehingga dapat dipahami bahwa komunikasi agama terjadi perlahan melakukan reduksi pada makna agama yang pernah dipahami sebelumnya, sebagaimana pandangan Beyer, "Agama bukan lagi sistem

\footnotetext{
1 Abdullah Irwan, "Di Bawah Bayang-Bayang Media: Kodifikasi, Divergensi, dan
} Kooptasi Agama di Era Internet," Jurnal Sabda, Fakultas Ilmu Budaya UGM (2017), 22. 
nilai dan norma yang melingkupi aspek-aspek kehidupan manusia, melainkan salah satu alternatif norma yang bersifat optional, penyempitan makna agama terbatas pada hal-hal yang bersifat ritual."

Sejatinya, dakwah menjadi sebuah penopang utama dalam komunikasi agama karena melalui dakwah pesan-pesan agama akan tersampaikan. Di era media baru seperti saat ini, sangat memungkinkan bagi dakwah melalui tulisan (dakwah bil qalam) untuk dikembangakan sebagai salah satu media dakwah yang penyampaiannya secara luas. Menurut Yafie, dakwah bil qalam pada dasarnya menyampaikan informasi tentang Allah, tentang alam (makhluk-makhluk) dan tentang hari akhir (nilai keabadian hidup). Dakwah model ini merupakan dakwah tertulis melalui media cetak. ${ }^{3}$ Sedangkan menurut Rahmat, ${ }^{4}$ dalam Islam Aktual, mengatakan bahwa dakwah bil qalam adalah dakwah melalui media cetak. Mengingat kemajuan teknologi informasi yang memungkinkan seorang berkomunikasi secara intens dan menyebabkan pesan dakwah bisa menyebar seluas-luasnya, maka dakwah lewat tulisan mutlak memanfaatkan kemajuan teknologi informasi.

Lebih lanjut, Hartono menjelaskan fungsi dakwah bil qalam dalam tiga hal, yaitu 1) melayani kebutuhan masyarakat akan informasi Islam. Informasi Islam yang dimaksud di sini adalah informasi yang bersumber dari al-Qur'an dan Hadis. 2) Berupaya mewujudkan atau menjelaskan seruan al-Qur'an secara cermat melalui berbagai media cetak untuk mengembalikannya kepada fikrah dan keuniversalannya, serta menyajikan produk-produk Islam yang selaras dengan pemikiran. 3) Menghidupkan dialog-dialog yang bernuansa pemikiran, politik, budaya, sosial, dan lain-lain. ${ }^{5}$ Aktivitas dakwah bi qalam dapat dilakukan

2 Moch. Fakhruroji, Dakwah di Era Media Baru (Bandung: Simbiosa Rekatama Media, 2017), 194.

3 Ali Yafie, Khazanah Informasi Islam (Jakarta: Pustaka Panji Mas, 1989), 255.

4 Jalaludin Rahmat, Islam Aktual: Refleksi sosial Cendekiawan Muslim (Bandung: Mizan, 1998), 172.

5 A. Jaiz Hartono, Meluruskan Dakwah dan Fikrah (Jakarta: Pustaka al-Kautsar, 1996), 174. 
melalui berita. Hal ini yang dilakukan oleh beberapa portal berita online, yang di antaranya menjadi analisis penulis adalah serambinews.com dan panjimas.com. Kedua portal berita online ini memiliki visi misi pengembangan dakwah melalui tulisan (dakwah bil qalam) yang salah satunya diimplementasikan dalam berita. Berita-berita yang disajikan marak akan pesan-pesan dakwah sehingga para pembaca (mad'u), selain mendapatkan informasi mengenai berita-berita terkini, berita tersebut juga dikaji dan dilihat dari sudut pandang Islam.

Hal ini menjadi menarik untuk dianalisis lebih lanjut oleh penulis di tengah maraknya berita palsu (hoax) yang menjamur melalui internet, justru serambinews.com dan panjimas.com justru membingkai berita dalam agenda dakwah. Bagaimana pesan-pesan dakwah dalam beritaberita yang ditampilkan oleh kedua portal ini dan bagaimana analisis framing kedua portal berita online berbasis Islam ini? Untuk itu penulis melakukan analisis terhadap pemberitaan yang tengah hangat saat ini tentang LGBT dalam dua portal berita online tersebut dengan menggunakan analisis framing.

Framing merupakan proses seleksi dari berbagai aspek realitas sehingga bagian tertentu dari peristiwa itu lebih menonjol dibandingkan aspek lain. Framing juga menyertakan penempatan informasi dalam konteks yang khas sehingga sisi tertentu mendapat alokasi lebih besar daripada sisi yang lain. Dalam tulisan ini, model yang digunakan adalah analisis framing Robert N. Entman yang terdiri dari elemen define problems (mendefinisikan masalah), diagnose cause (memperkirakan masalah atau sumber masalah), make moral judgement (membuat keputusan moral), dan suggest remedies (menekankan penyelesaian). ${ }^{6}$

\section{Frame Serambinews.com: Nerangkul LGBT}

Hal pertama yang dilakukan adalah problem identification atau identifikasi masalah. Portal berita online serambinews.com menurunkan

${ }^{6}$ Eriyanto, Analisis Framing: Konstruksi, Ideologi, dan Politik Media (Yogyakarta: LkiS, 2004), 189. 
laporan mengenai pemberitaan LGBT dengan judul "Menteri Agama Imbau Masyarakat Tak Jauhi Kelompok LGBT Tapi Dirangkul”.7 Serambinews.com mengidentifikasikan pertama-tama berita tentang LGBT dilihat dari konteks sosial kemasyarakatan. Serambinews.com melihat bagaimana LGBT seharusnya diterima di masyarakat dan memiliki hak yang sama dengan masyarakat lainnya.

Ada beberapa alasan, mengapa penulis mengatakan bingkai sosial kemasyarakatan sebagai bingkai yang dominan dalam pemberitaan serambinews.com. Pertama, semua masalah ditelaah dalam perspektif sosial, artinya serambinews.com melihat bagaimana permasalahan LGBT ini yang seharusnya dilihat bukan saja dalam konteks agama, tapi juga dalam konteks sosial. Dengan dasar wawancara bersama Menteri Agama Lukman Hakim Saefuddin, serambinews.com berusaha menjabarkan beberapa hal yang seharusnya dilakukan oleh masyarakat, terutama umat Islam ketika menganggapi isu LGBT. Kaum LGBT menurut Menteri Agama harus dirangkul, bukan dijauhi apalagi dimusuhi. Kedua, masih dalam perspektif sosial kemasyarakatan, bagaimana pernyataan Menteri Agama secara tegas menyatakan bahwa tidak ada agama yang mentolerin tindakan LGBT, namun bagaimana masyarakat menyikapi mereka yang memiliki orientasi seksual seperti itu. Hal ini dapat dipahami, bahwa Menteri Agama dalam hal ini ingin mengajak masyarakat melihat persoalan LGBT bukan dari kacamata agama semata, tapi juga dari kacamata sosial. Jika dalam perspektif agama, sudah jelas bahwa LGBT dilarang, tetapi sebagai makhluk sosial, mereka memiliki hal yang sama dengan yang lainnya. Ketiga, Menteri Agama meminta masyarakat untuk merangkul, mengayomi, dan tidak menjauhi mereka yang terindikasi LGBT. Hal ini merupakan salah satu bentuk dari dakwah bi hal, bagaimana sikap seorang muslim kepada muslim lainnya atau mereka yang non-muslim, sebagaimana akhlak yang telah dicontohnya Rasulullah SAW. Pendeknya, serambinew.com mengidentifikasi permasalahan LGBT sebagai masalah sosial kemasyarakatan.

\footnotetext{
7 Lihat, https:// serambinews.com. Diakses pada 2 Maret 2018.
} 
Causal interpretation. Secara tidak langsung serambinews.com memposisikan masyarakat dalam hal ini umat muslim sebagai akar permasalahan. Masyarakat yang menolak, bahkan banyak yang melakukan tindakan yang tidak menyenangkan kepada LGBT justru menjadi awal permasalahan, sehingga untuk meredam kondisi masyarakat, terutama umat Islam di tanah air, serambinews.com melalui wawancara dengan Menteri Agama mengharapkan masyarakat untuk tenang, berpikir jernih dan tidak melakukan hal-hal negatif lainnya, yakni dengan mengajak agar merangkul kaum LGBT. Sebaliknya, LGBT dalam kacamata serambinews.com sebagai aktor yang tertindas, yang seharusnya dilindungi bukan dijauhi.

Moral evaluation. Masyarakat yang diposisikan sebagai sumber dari segala permasalahan yang ada dianggap harus melihat permasalahan LGBT bukan hanya dalam konteks agama, tapi juga sosial kemasyarakatan. Bahwa ada hak-hak asasi LGBT untuk tetap tinggal dengan nyaman di negera mereka sendiri, bahkan tugas seorang muslim untuk mendakwahi mereka. Menteri Agama mengungkapkan klaim moral atas kasus ini.

Mereka harus dirangkul dan diayomi, bukan justru dijauhi dan dikucilkan. Justru kewajiban kita para penganut agama, bahwa agama itu adalah mengajak. Kalau kita menganggap hal tersebut adalah tindakan yang sesat, maka kewajiban kita untuk mengajak kembali mereka ke jalan yang benar. ${ }^{8}$

Dari pernyataan tersebut dapat dipahami bahwa justru tugas seorang muslim untuk melakukan dakwah kepada LGBT dengan cara yang baik, dirangkul, dan diayomi. Dengan menjauhi dan mengucilkan mereka, pesan-pesan dakwah tidak dapat disampaikan dengan baik, mereka akan semakin memandang Islam buruk. Hal ini tercermin dari masayarakatnya. Jika melihat dakwah Rasulullah Saw. terhadap mereka yang menolak dakwah rasul dilakukan dengan baik, secara kasih sayang dan bukan dengan kekerasan.

\footnotetext{
8 Lihat pernyataan Meteri Agama mengenai kasus tersebut dalam www.serambinews. com. Diakses pada 2 Maret 2018.
} 
Treatment recommendation. Dari berita tentang LGBT tersebut, serambinews.com "merekomendasikan" agar permasalahan ini diselesaikan dengan jalan yang damai, tanpa ada kekerasan dan permusuhan. Karena sejatinya, Islam hadir sebagai rahmatan lil alamin, rahmat bagai semesta alam. Maka dari itu, masyarakat dihimbau untuk merangkul kaum LGBT, agar permasalahan LGBT tidak berlarut-larut. Ini sebagai konsekuensi logis dari serambinews.com melihat kasus ini dalam kacamata sosial kemasyarakatan.

\section{Frame panjimas.com: LGBT Merusak Moral Bangsa}

Portal berita online panjimas.com juga menurunkan laporan mengenai LGBT, yang diberi judul "Jika LGBT dibiarkan Negara Akan Rusak”. Berita ini adalah hasil wawancara dengan Ustaz Abdul Rochim Ba’asyir terkait LGBT. ${ }^{9}$

Problem identification. Panjimas.com mengidentifikasi persoalan LGBT dalam perspektif agama. LGBT dianggap menjadi salah satu penyebab Indonesia mengalami krisis moralitas. Dengan berbagai persoalan yang dihadapi Indonesia saat ini, telah menunjukkan bahwa bangsa ini telah mengalami darurat kejahatan asusila. Perkembangan LGBT yang tampak dan meningkat di Indonesia dikhawatirkan akan merusak moral bangsa, terutama generasi muda. Indonesia sejatinya adalah negara yang berlandaskan hukum dengan menjunjung tinggi nilai-nilai moral dan budi pekerti luhur, tidak boleh dirusak dengan adanya LGBT.

Selanjutnya, bagaimana panjimas.com membingkai beritanya dalam konteks agama dengan menjelaskan LGBT dalam pandangan Islam, serta azab yang akan diterima jika masyarakat dan pemerintah tidak tegas dalam membendung LGBT. Perkembangan LGBT di Indonesia dirasa mulai meresahkan masyarakat, dengan tidak adanya regulasi yang mengatur secara tegas sanksi yang diberikan kepada kaum LGBT, membuat masyarakat dan negara tidak bisa menindak LGBT. Oleh karena

\footnotetext{
${ }^{9}$ Lihat, www.panjimas.com. Diakses pada 3 Maret 2018.
} 
itu, Negara harus secara tegas membuat regulasi yang termaktub dalam UUD untuk mempidanakan para LGBT di Indonesia, bukan hanya korbannya yang dibawah umur, tetapi juga mereka yang telah dewasa.

Causal interpretation. Panjimas.com memposisikan kaum LGBT sebagai aktor dari permasalahan. LGBT adalah penyebab dari rusaknya moral bangsa, sebab LGBT dianggap sebagai perbuatan menyimpang dan tidak ada agama manapun yang membolehkan perilaku LGBT, terutama Islam. Untuk pengaturan dalam perundang-undangan pemerintah harus secara tegas menindak LGBT. Hal ini dilakukan, selain memendung pergerakan LGBT, juga diharapkan agar generasi muda dapat terselamatkan dari perbuatan LGBT. Jika apa yang dilakukan LGBT dibiarkan begitu saja, secara nyata dan meluas bahkan dapat dilihat oleh para generasi muda, maka akan sangat memungkinkan mereka generasi muda mengikuti LGBT, karena dalam pandangan panjimas.com, LGBT adalah perbuatan menyimpang yang dapat merusak tatanan kehidupan masyarakat Indonesia yang dibangun di atas moral dan nilai-nilai ketuhanan.

Moral evaluation. Penilaian atas LGBT sebagai sumber masalah, yang mendatangkan dua hal yang negatif. Pertama, LGBT dianggap sebagai awal mula merosotnya moral bangsa. Banyak kejadian di Indonesia terutama anak yang menjadi korban sehingga seharusnya adanya regulasi yang dapat memidanakan tindakan LGBT bukan hanya korbannya anak, tapi juga mereka yang sudah dewasa. Kedua, LGBT adalah penyakit yang merusak kejiwaan, yang jika dibiarkan maka perlahan LGBT akan merusak jiwa bangsa ini. Dengan melihat LGBT sebagai penyakit, maka seyogyanya harus disembuhkan dengan menekan dan menghambat perkembangan LGBT di Indonesia. Dalam hal ini masyarakat harus tegas melihat persoalan LGBT tidak boleh dibiarkan begitu saja, karena jika masyarakat tidak bertindak ditambah dengan pemerintah juga tidak memberikan sanksi, bukan tidak mungkin Indonesia akan merima azab sebagaimana yang pernah terjadi pada kaum Nabi Luth.

Treatment Recommendation. Dalam berita panjimas.com secara tidak langsung merekomendasikan bahwa pemerintah harus tegas menindak LGBT. Selain itu, perlu peran serta masyarakat yang tidak 
tinggal diam melihat persoalan LGBT yang perlahan-lahan telah merusak moral bangsa juga generasi muda. Perilaku LGBT terutama korbannya anak-anak harus ditindak secara tegas dengan adanya regulasi yang jelas, begitupun mereka yang telah dewasa jangan dibiarkan melakukan tindakan yang dapat diikuti oleh yang lainnya, terutama dalam hal ini para remaja. Pemerintah dan masyarakat harus tegas melihat persoalan LGBT ini jika tidak ingin melihat Indonesia "sakit" serta menyelamatkan Indonesia dari krisis moralitas.

\section{Berita Sebagai Instrumen Dakwah}

Dengan melihat framing dari kedua media online serambinews.com dan panjimas.com sama-sama menjadikan dakwah sebagai basis utama pemberitaan. Hal ini dapat dilihat dari pemilihan kata yang berujung kepada dakwah. Namun, ada perbedaan di antara kedua media online tersebut dalam ideologi penyampaian pesan dakwah yang digunakan. Serambinews.com memilih menyampaikan pesan dakwah secara profetik, sementara panjimas.com memilih menyampaikannya secara provokatif. Penyampaian pesan dakwah secara profetik mengarah pada idealisme bahwa model jurnalisme profetik merupakan jurnalisme kenabian yang mengupayakan penyebaran informasi dan berita dengan penggunaan bahasa yang lebih ramah, santun, damai, merangkul, dan dialogis. Harapannya, umat lebih menemukan pencerahan, pendidikan, kedamaian, dan keterbukaan hati pikiran untuk memahami substansi Islam secara esensial. Dalam konteks ini, isi kualitas berita lebih ditonjolkan ketimbang soal isu ideologi Islamisme semata. Tipe ini juga muaranya pada penciptaan perdamaian (peace building-oriented), anti kekerasan, dan anti konflik. Semangat berjihad membangun masyarakat plural dan multikultural sangat menonjol sembari menyuarakan progresivisme, liberalisme, dan anti-radikalisme. ${ }^{10}$

\footnotetext{
${ }^{10}$ Choirul Mahfud, "Ideologi Media Islam Indonesia dalam Agenda Dakwah: Antara Jurnalisme Profetik dan Jurnalisme Provokatif," Jurnal Dakwah (2014), 4.
} 
Penyampaian pesan-pesan dakwah secara profetik terlihat dari berita tentang LGBT di serambinews.com. Media online ini bukan bermaksud untuk mendukung LGBT, tapi mengajak masyarakat untuk menyampaikan pesan-pesan dakwah secara damai, tanpa kekerasan. Apa yang dilakukan serambinews.com memperlihatkan kepada kita bahwa dakwah dapat dilakukan dengan hikmah, sebagaimana dalam al-Qur'an Surat anNahl ([16]: 125) sebagai berikut:

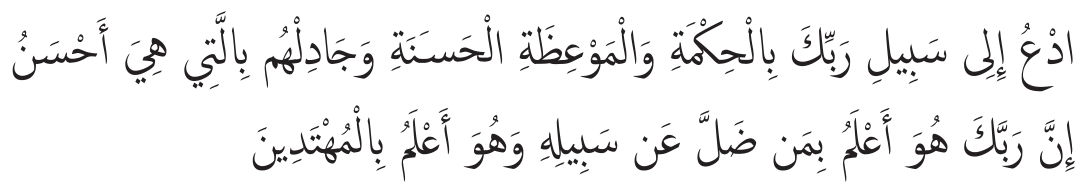

Serulah (manusia) kepada jalan Tuhan-mu dengan hikmah dan pelajaran yang baik dan bantahlah mereka dengan cara yang baik. Sesungguhnya Tuhan-mu Dialah yang lebih mengetahui tentang siapa yang tersesat dari jalan-Nya dan Dialah yang lebih mengetahui orang-orang yang mendapat petunjuk.

Ayat tersebut dapat dipahami bagaimana konsep dakwah dengan kata-kata yang baik, tindakan yang penuh kasih sayang tanpa kekerasan serta dengan penuh kedamaian, sebab sesungguhnya Allah maha mengetahui terhadap kondisi umatnya. Metode dakwah yang dilakukan oleh serambinews.com melalui beritanya merupakan suatu metode yang baik untuk diterapkan dengan kondisi masyarakat Indonesia saat ini. Dakwah secara kekerasan oleh segelintir orang justru membuat mereka yang "di luar” Islam memandang Islam secara negatif. Sebaliknya, dakwah yang dilakukan dengan cara-cara dan keteladanan yang baik (hasanah) akan mudah diterima dan (hikmah) menyentuh hati mereka. Dakwah seperti ini sangat dibutuhkan dengan kondisi masyarakat Indonesia yang haus akan pesan-pesan dakwah yang menenteramkan, mendamaikan, dan menyejukkan. Jika melihat apa yang ditampilkan oleh sebagaian besar media online saat ini, kita akan disuguhi berita-berita yang mengundang konflik. Menjadikan hukum Islam sebagai landasan, tanpa melihat hal-hal lain yang bersifat universal. Hukum Islam boleh saja ditegakkan, namun satu hal yang perlu diingat bahwa Indonesia bukanlah negara 
Islam, tapi negara yang berideologi Pancasila. Meskipun masyarakat Indonesia mayoritas muslim, tapi ada hak masyarakat lain di luar Islam yang juga perlu diakomodir hak dan kepentingan mereka. Begitupun dengan permasalahan LGBT, Islam harus hadir sebagai pemberi solusi dengan jalan yang damai, bukan permusuhan atau kekerasan. Ini adalah secercah pesan dakwah yang ingin disampaikan serambinews.com bahwa Islam membawa kedamaian.

Sementara itu, penyampaian pesan dakwah secara provokatif dapat dipahami dari penggunaan bahasa dan penyajian berita yang dilakukan oleh pimpinan dan redaksi media Islam yang cenderung lebih ke arah normatif, provokatif, intimidatif, hingga anti-dialogis. Media seperti ini lawan dari media jurnalisme profetik. Karakteristik dan bahasa media ini tampak provokatif dan menebar permusuhan serta mengundang konflik. Meskipun demikian, ada beberapa hal positif yang coba hendak dihadirkan media, terutama media online panjimas.com dalam cara penyampaian dakwahnya. Meskipun dengan cara penyampaian yang provokatif, dapat penulis pahami bahwa ada semangat dakwah yang begitu kuat untuk menegakkan syariat Islam. Hal ini dilakukan agar umat Islam tidak tergiur dengan hal-hal yang bersifat sosial kemanusiaan, namun tidak sesuai dengan akidah dan ajaran Islam. Apa yang dilakukan panjimas.com merupakan penyampaian dakwah secara tegas, meskipun demikan harus juga diperhatikan bagaimana efek dakwah dan resepsi pembaca (mad'u) terhadap pemberitaan tersebut.

\section{Penutup}

Dari analisis framing yang dilakukan penulis, dapat disimpulkan bahwa media online serambinews.com membingkai berita tentang LGBT sebagai permasalahan sosial kemasyarakatan. Masyarakat dihimbau untuk merangkul LGBT sebagai bagian dari masyarakat yang memiliki hak yang sama dengan masyarakat lainnya. Penyampaian pesan dakwah melalui serambinews.com dilakukan secara profetik, yakni dengan menggunakan kata-kata yang baik agar masyarakat terutama umat muslim tidak menjauhi atau mengucilkan LGBT. Pesan dakwah secara profetik 
dimaksudkan agar masyarakat melakukan dakwah secara hikmah agar kaum LGBT merasa bahwa meraka juga dihargai hak-haknya. Dengan demikian, berdakwah akan suatu kebaikan terlebih persoalan agama mestinya disampaikan dengan cara yang baik pula.

Berbeda dengan serambinews.com, media online panjimas.com melihat bahwa permasalahan LGBT adalah permasalahan moral yang harus segera diselesaikan. Masyarakat terutama umat Islam harus tegas melihat permasalahan ini, karena jika dibiarkan LGBT akan merusak moral bangsa, terutama generasi muda. Untuk itu, perlu upaya-upaya agar hal tersebut tidak terjadi; umat Islam di Indonesia harus bersatu memaksa agar pemerintah membuat sebuah aturan baku untuk memidanakan LGBT agar tidak menyebarkan hal yang tidak baik kepada masyakarat. Panjimas.com memilih menyampaikan pesan-pesan dakwah melalui beritanya secara provokatif, menyampaikan dengan tegas, mengajak dengan kata-kata yang intimidatif hingga mengundang konflik. Para pembaca (mad'u) yang masih awam tentu mempercayai sepenuhnya apa yang disampaikan dalam berita tersebut, tanpa berusaha melihat alternatif lainnya. Di satu sisi penyampaian pesan dakwah secara provokatif ada baiknya, tetapi di sisi laini harus ada pertimbangan-pertimbangan sosial sebagai dampak dari penyampaian pesan dakwah tersebut.

Penyampaian pesan dakwah baik secara profetik maupun provokatif memiliki kelebihan dan kekurangan masing-masing. Profetik dengan bahasa yang lembut dan jalan yang damai terkadang tidak tepat sasaran, terutama dalam kondisi masyarakat yang mulai berpikir secara individualis. Dengan kondisi masyarakat yang mulai "acuh tak acuh" perlu diberi penyampaian pesan-pesan dakwah secara tegas dengan menggunakan bahasa ideologis dan berlandaskan Islam agar masyarakat melihat bahwa permasalahan ini bukan lagi permasalahan biasa. Penggunaan bahasa yang provokatif di satu sisi memicu adanya konflik, tetapi di sisi lain dapat menggugah masyarakat untuk melihat permasalahan ini menjadi permasalahan bersama. Penyampaian pesan dakwah secara profetik maupun provokatif, dapat dilihat dari kondisi mad'u yang menerima pesan-pesan dakwah tersebut, sehingga tidak dapat digeneralisir, apalagi 
menggunakan media massa sebagai media perantaranya. Hal ini sangat memungkinkan pesan dakwah tidak tersampaikan dengan baik, karena segmentasi mad'u yang tidak tepat sasaran.

\section{DAFTAR PUSTAKA}

Sobur, Alex. Analisis Teks Media: Suatu Pengantar untuk Analisis Wacana, Analisis Semiotik dan Analisis Framing. Bandung: PT. Remaja Rosdakarya, 2015.

Eriyanto. Analisis Framing: Konstruksi, Ideologi, dan Politik Media. Yogyakarta: LkiS, 2004.

Fakhruroji, Moch. Dakwah di Era Media Baru. Bandung: Simbiosa Rekatama Media, 2017.

Irwan, Abdullah. "Di Bawah Bayang-Bayang Media: Kodifikasi, Divergensi, dan Kooptasi Agama di Era Internet." Jurnal Sabda. Fakultas Ilmu Budaya UGM (2017).

Hartono, A. Jaiz. Meluruskan Dakwah dan Fikrah. Jakarta: Pustaka alKautsar, 1996.

Mahfud, Choirul. "Ideologi Media Islam Indonesia dalam Agenda Dakwah: antara Jurnalisme Profetik dan Jurnalisme Provokatif." Jurnal Dakwah (2014).

Rahmat, Jalaludin. Islam Aktual: Refleksi sosial Cendekiawan Muslim. Bandung: Mizan, 1998.

Yafie, Ali. Khazanah Informasi Islam. Jakarta: Pustaka Panji Mas, 1989.

\section{Sumber Online:}

"Menteri Agama Imbau Masyarakat Tak Jauhi Kelompok LGBT Tapi Dirangkul." www.serambinews.com. Diakses pada 2 Maret 2018.

"Jika LGBT dibiarkan Negara Akan Rusak." www.panjimas.com. Diakses pada 3 Maret 2018. 